Supporting Information

\title{
Proton Removal Kinetics That Govern the Hydrogen Peroxide Oxidation Activity of Heterogeneous Bioinorganic Platforms
}

Wanying Wang, ${ }^{1}$ Edmund C. M. Tse ${ }^{*, 1,2}$

${ }^{1}$ Department of Chemistry, HKU-CAS Joint Laboratory on New Materials, University of Hong Kong (HKU), Pok Fu Lam, Hong Kong Special Administrative Region, China

${ }^{2}$ HKU Zhejiang Institute of Research and Innovation, Zhejiang 311305, China

* Corresponding author. E-mail: ECMT ecmtse@ @hu.hk

Supplementary Figures S1-S12 on Ligand Synthesis, ICP-MS Plot, Cyclic Voltammograms, Tafel Analyses, Theoretical Calculations, and Simulated Structures

Supplementary Table S1 on XPS Data

Supplementary Note 1 on Biophysical Modelling Results

Supplementary References 

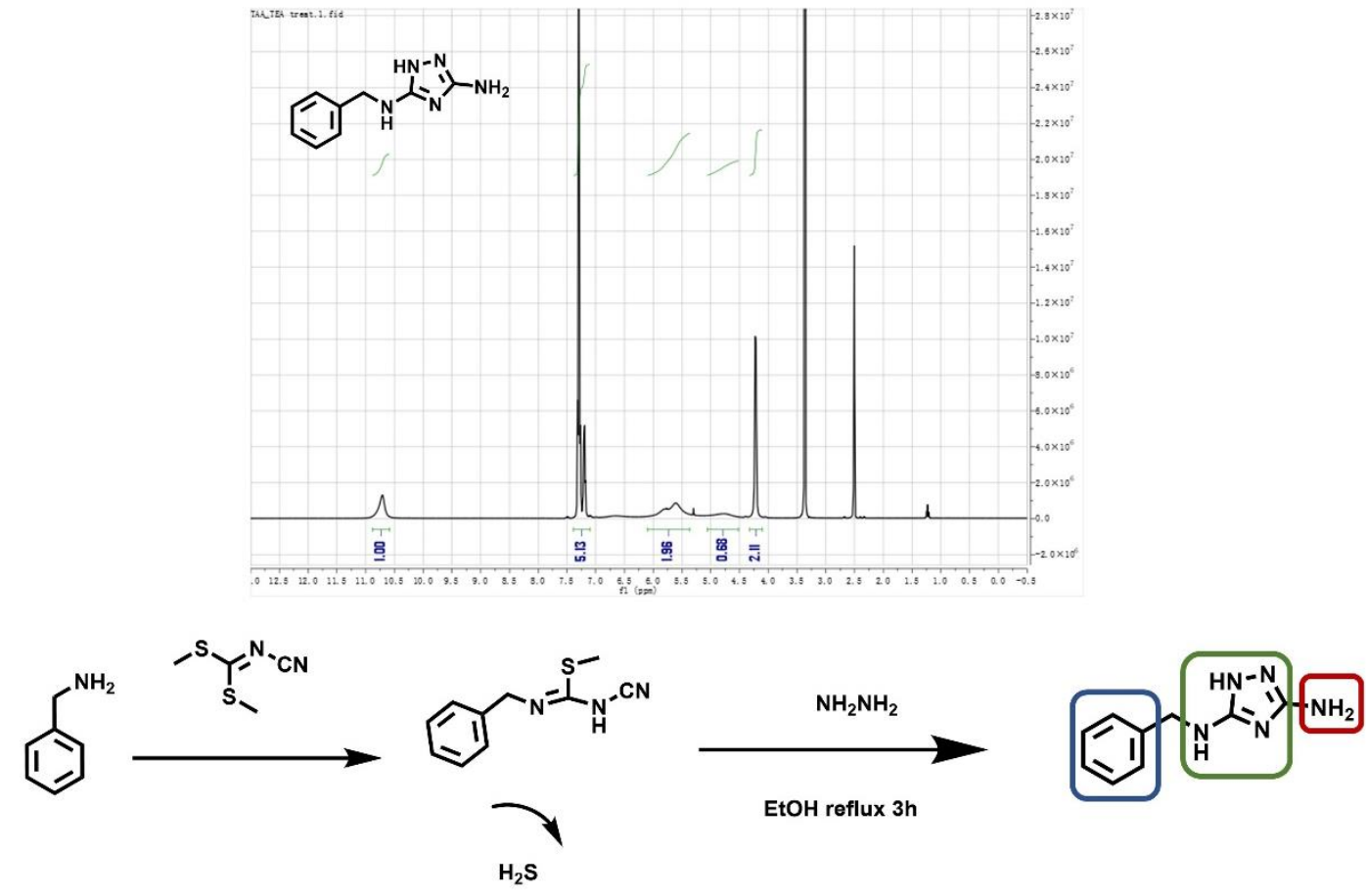

Figure S1. NMR spectra and functional units of BTA.

The synthetic procedure and molecular characterization of BTA were reported elsewhere. ${ }^{1}$ 


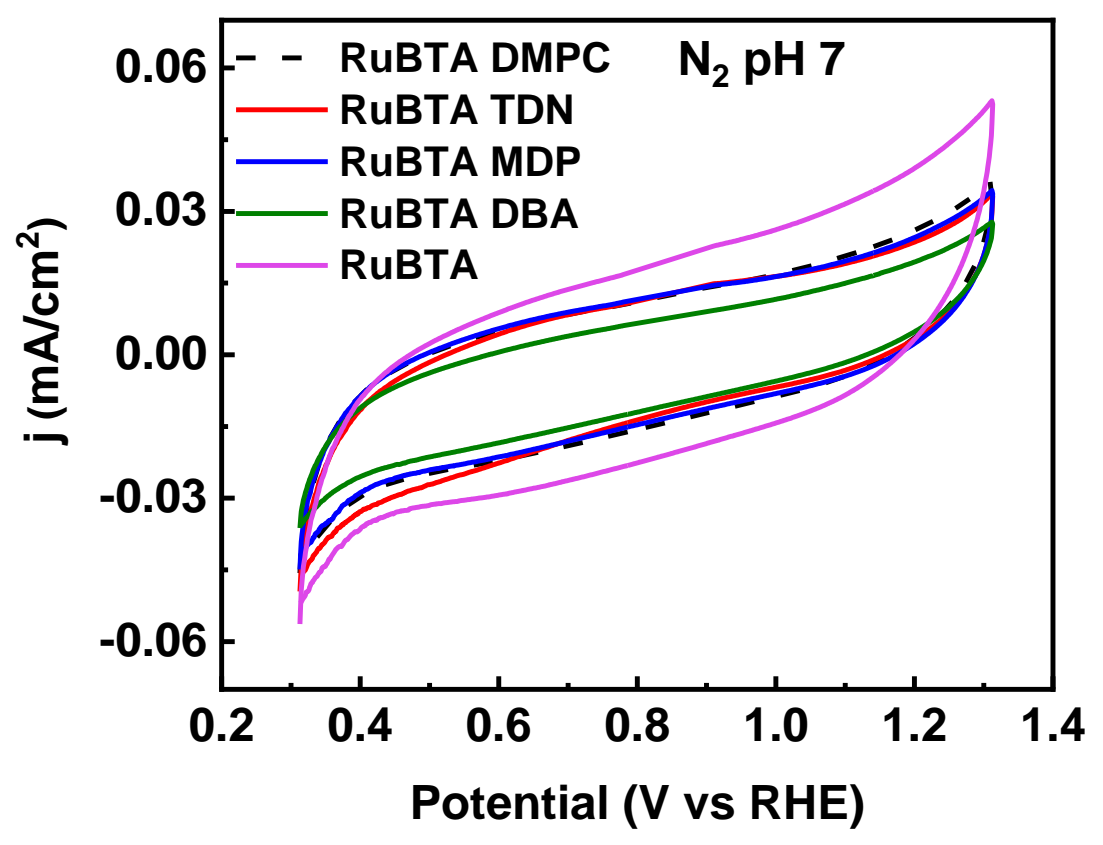

Figure S2. Cyclic voltammograms (CVs) of a SAM of the RuBTA complex (magenta), a HBM containing RuBTA with a lipid layer (black dashed), a HBM containing RuBTA with proton carriers incorporated in the lipid layer $($ red $=\mathrm{TDN}$, blue $=\mathrm{MDP}$, green $=$ DBA).

Under an inert $\mathrm{N}_{2}$ atmosphere, the redox peak of the open SAM with and without Ru cannot be clearly identified. We hypothesize that the high capacity of GC masks the Faradaic redox wave of Ru centers, the presence of which can be confirmed using XPS. The charging current decreased upon the incorporation of the lipid membrane, consistent with previous reports on analogous HBM systems . .,3 
(a)

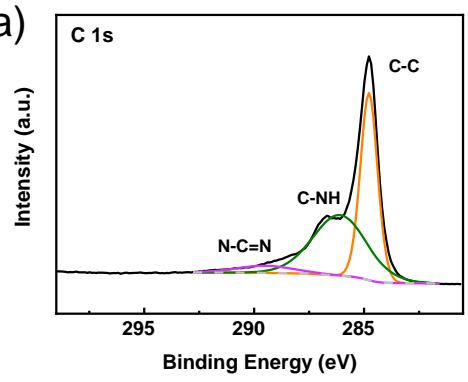

(b)

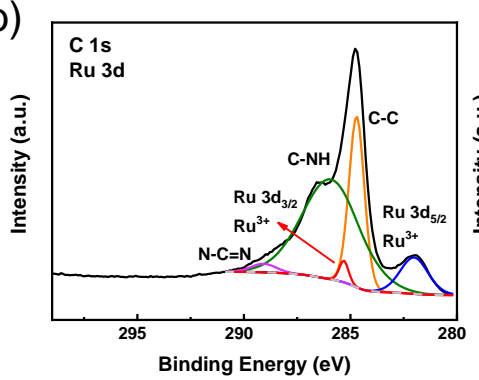

(c)
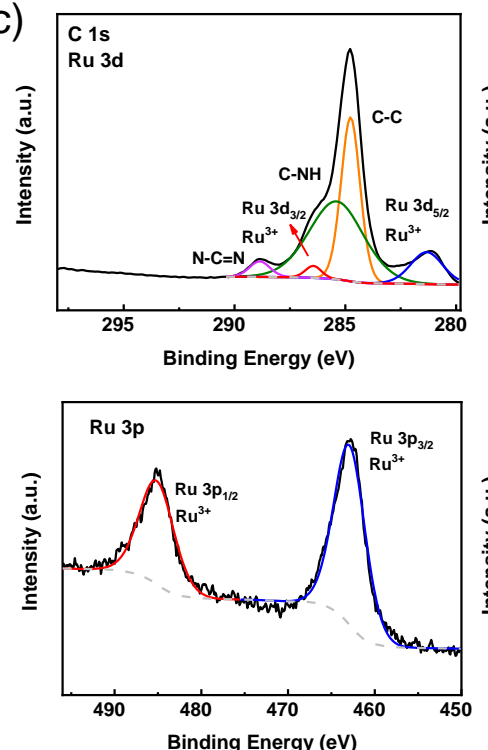

(d)
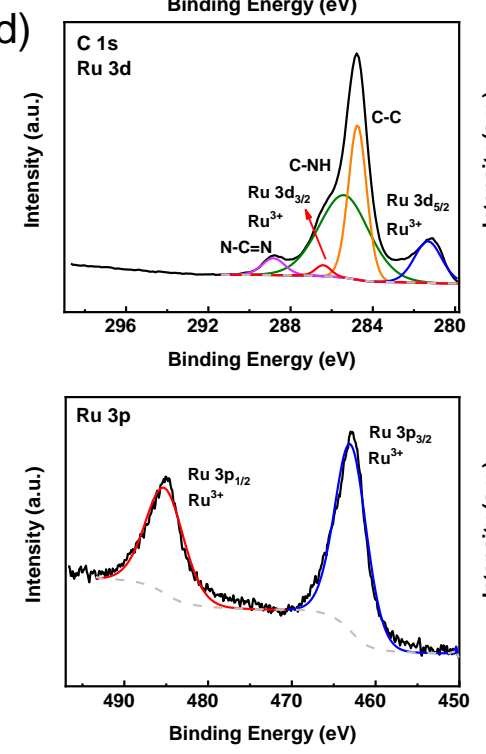
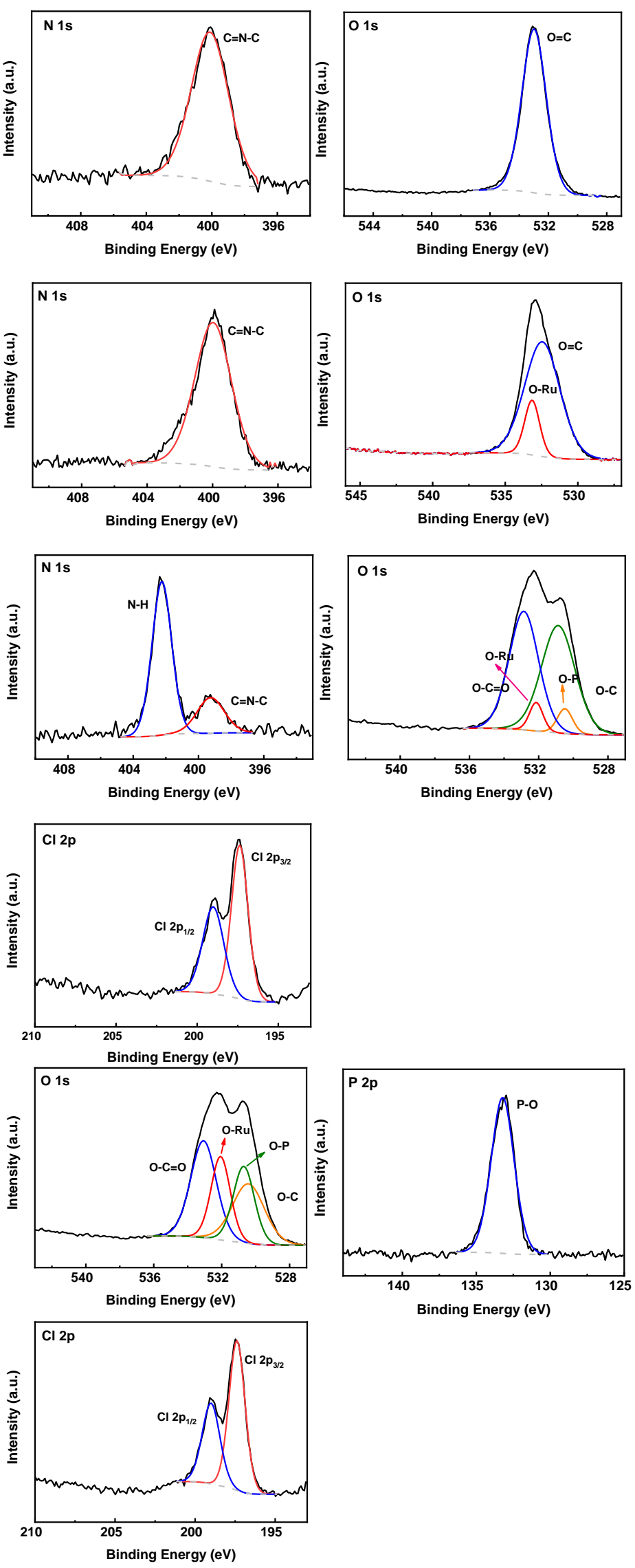
(e)
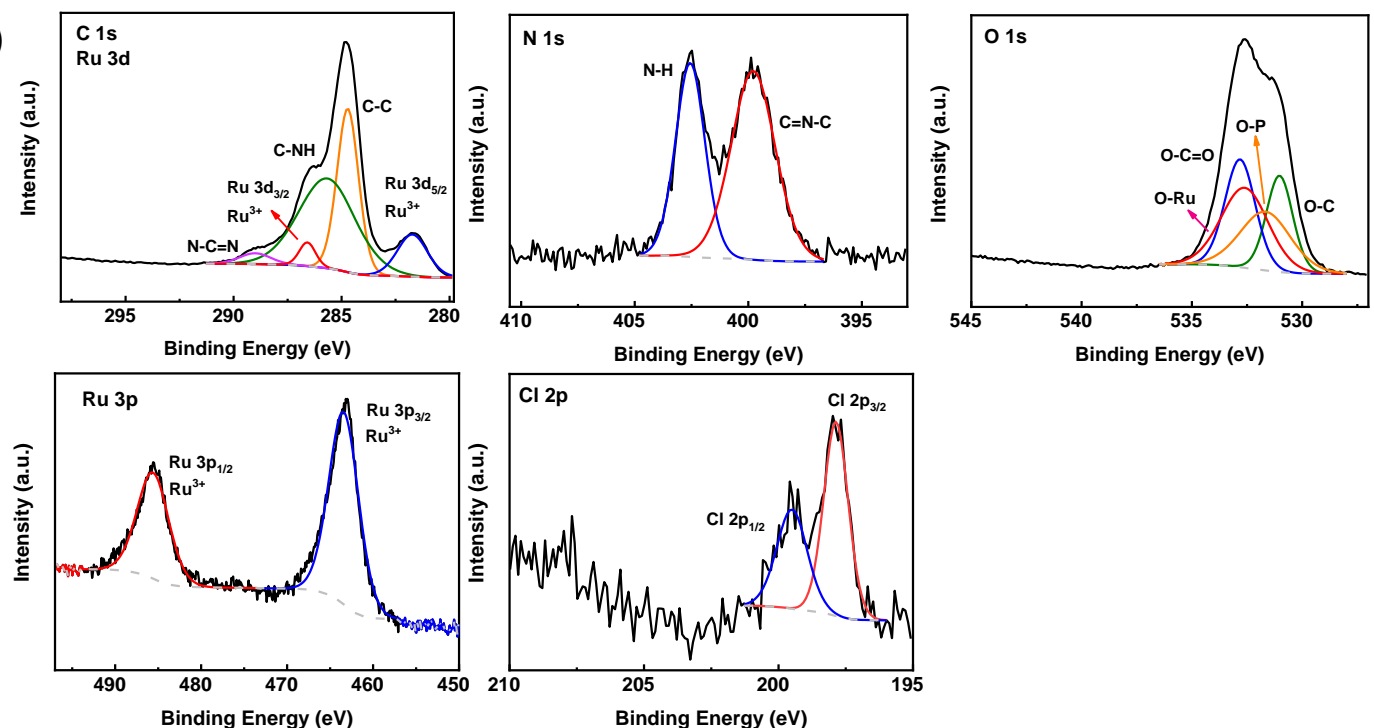

(f)
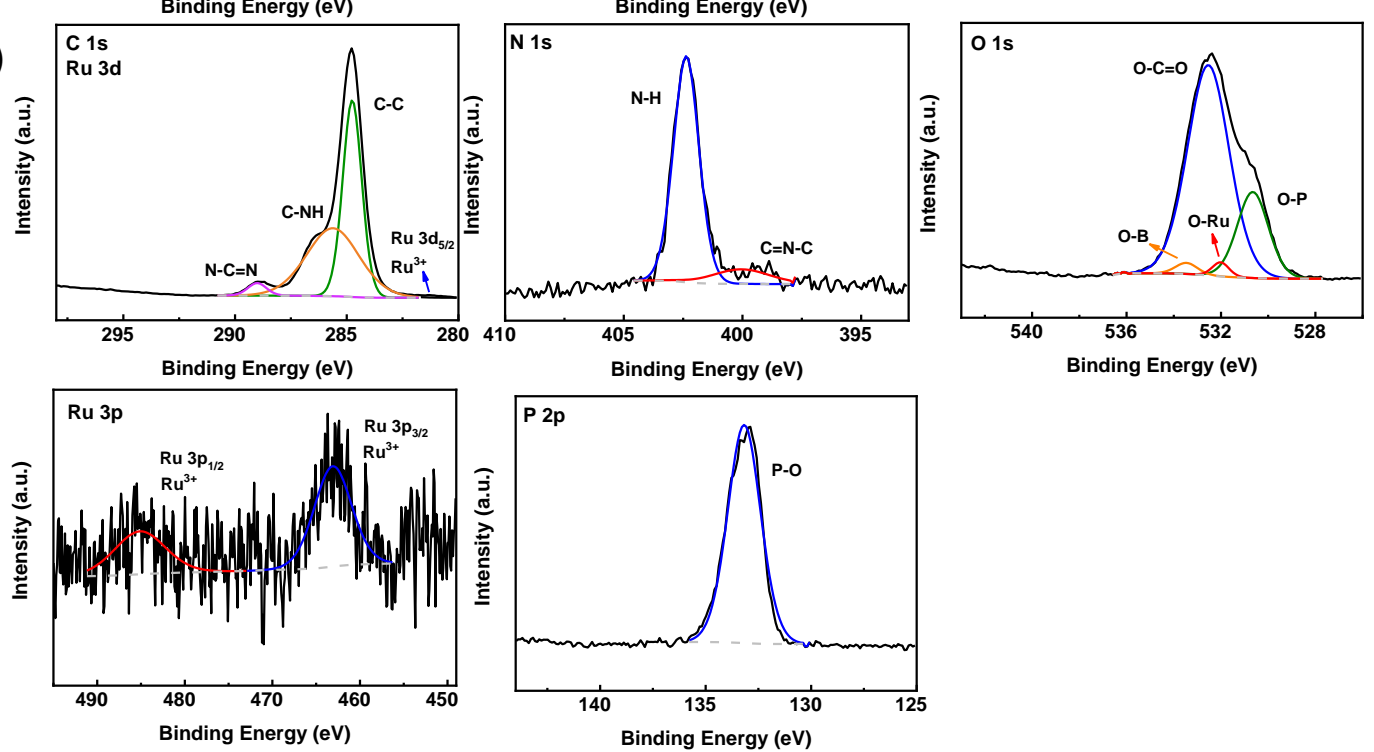

Figure S3. XPS high-resolution scans of (a) BTA open SAM: C 1s, N 1s, O 1s; (b) RuBTA open SAM: C 1s, N 1s, O 1s; (c) RuBTA HBM with lipid only: C 1s, N 1s, O 1s, Cl 2p, Ru 3p; (d) RuBTA HBM with TDN in the lipid layer: $\mathrm{C} \mathrm{1s,} \mathrm{O} \mathrm{1s,} \mathrm{Cl} \mathrm{2p,} \mathrm{Ru}$ 3p, P 2p; (e) RuBTA HBM with MDP in the lipid layer: C 1s, N 1s, O 1s, Cl 2p, Ru 3p; and (f) RuBTA HBM with DBA in the lipid layer: C 1s, N 1s, O 1s, Ru 3p, P 2p. 
Elemental compositions were calculated using the equation below:

$$
\begin{aligned}
& \boldsymbol{n}_{\boldsymbol{i}}: \boldsymbol{n}_{j} \\
& =\frac{\boldsymbol{l}_{\boldsymbol{i}} / \boldsymbol{s}_{\boldsymbol{i}}}{\boldsymbol{l}_{\boldsymbol{j}} / \boldsymbol{s}_{\boldsymbol{j}}}
\end{aligned}
$$

where $n$ is atom concentration, $l$ represents peak area, and $s$ represents relative sensitivity factor (RSFs) which can be obtained from XPS Scofield databases.

\begin{tabular}{ccccc}
\hline Element & $\mathbf{R u}$ & $\mathbf{N}$ & $\mathbf{C l}$ & $\mathbf{O}$ \\
\hline Peak & $3 \mathrm{p}_{1 / 2}$ & $1 \mathrm{~s}$ & $2 \mathrm{p}_{3 / 2}$ & $1 \mathrm{~s}$ \\
$\mathrm{l}_{\mathrm{i}}$ & 203450.3 & 591797.3 & 160410.5 & 140414.7 \\
$\mathrm{~s}_{\mathrm{i}}$ & 3.44 & 1.80 & 0.775 & 2.93 \\
$\mathrm{l}_{\mathrm{i}} / \mathrm{s}_{\mathrm{i}}$ & 59142.53 & 328776.3 & 206981.3 & 47923.11 \\
$\mathrm{n}_{\mathrm{i}} / \mathrm{n}_{\mathrm{Ru}}$ & 1 & 5.55905 & 3.499703 & 0.810299 \\
\hline
\end{tabular}

Table S1. Peak areas and sensitivity factors of $\mathrm{Ru}, \mathrm{N}, \mathrm{Cl}$, and $\mathrm{O}$ obtained from the XPS spectra of RuBTA powder. 


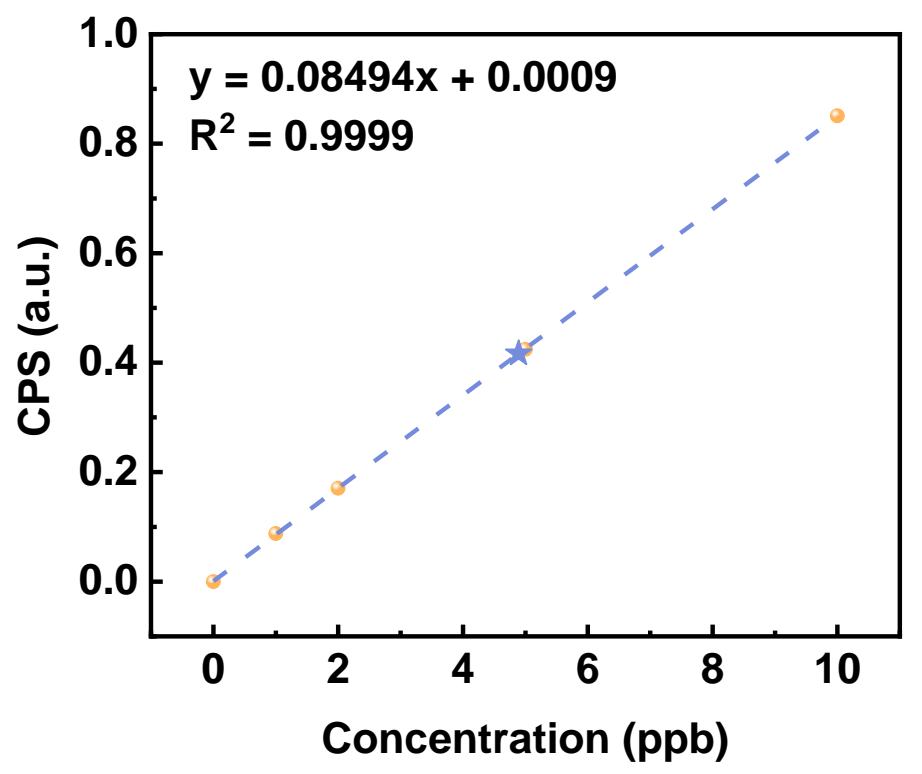

Figure S4. ICP-MS standard curve of Ru. The blue star represents the Ru sample concentration which is within the linear region. 


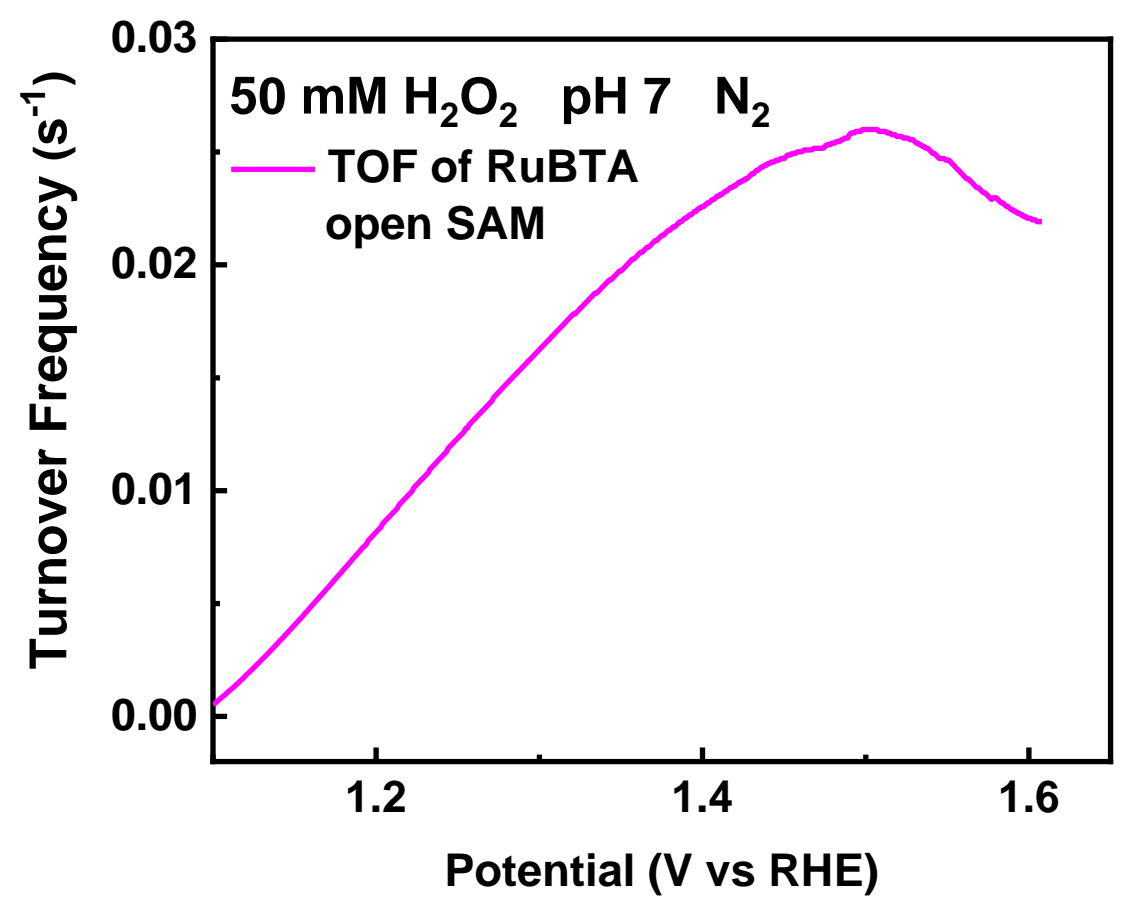

Figure S5. Turnover frequency (TOF) of RuBTA open SAM for $\mathrm{H}_{2} \mathrm{O}_{2}$ electrooxidation as a function of applied electrode potential.

Turnover frequency (TOF) in Figure S5 was calculated using the equation below:

$$
\begin{aligned}
& \text { TOF } \\
& =\frac{j \times A}{n \times F \times m}
\end{aligned}
$$

where $j$ is current density, $A$ is surface area, $n$ is number of electrons, $F$ is Faraday's constant, and $m$ is mole of catalysts. 
(a)
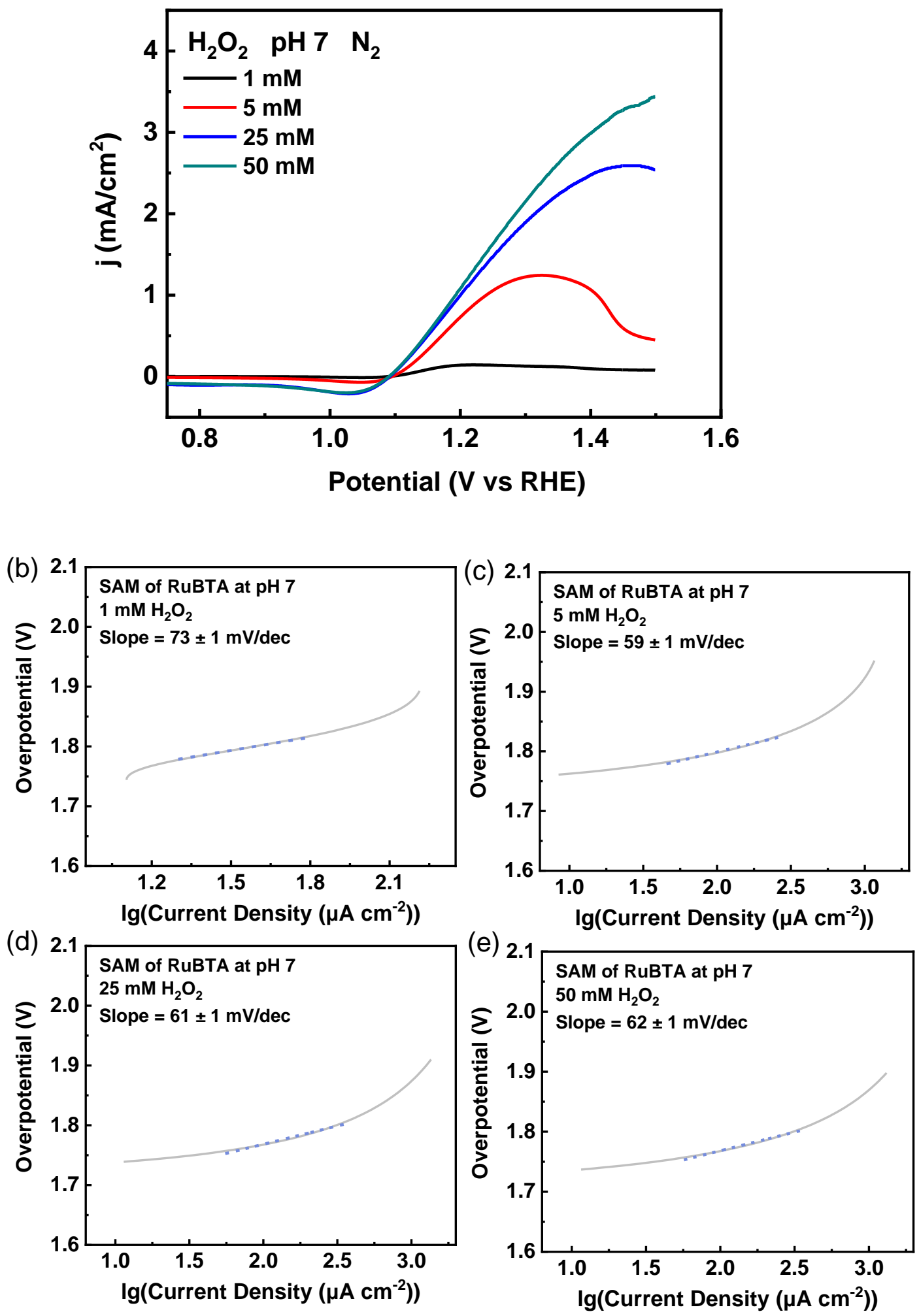

Figure S6. (a) $\mathrm{H}_{2} \mathrm{O}_{2}$ electrooxidation LSVs of RuBTA open SAM with different $\mathrm{H}_{2} \mathrm{O}_{2}$ concentrations. Tafel slopes obtained in $\mathrm{pH} 7$ buffer solutions with (b) $1 \mathrm{mM}$, (c) 5 $\mathrm{mM}$, (d) $25 \mathrm{mM}$, and (e) $50 \mathrm{mM} \mathrm{H}_{2} \mathrm{O}_{2}$. 


\section{Supplementary Note 1}

\section{$\mathrm{H}_{2} \mathrm{O}_{2}$ Diffusion Calculations}

The $\mathrm{H}_{2} \mathrm{O}_{2}$ diffusion rate through a lipid layer can be calculated by its local concentration and diffusion coefficient (D) in the lipid membrane. ${ }^{4}$ The flow rate of $\mathrm{H}_{2} \mathrm{O}_{2}$ can be described by Fick's law as

Flow Rate $=\frac{-\mathrm{D}\left[\mathrm{H}_{2} \mathrm{O}_{2}\right]}{\Delta x}$

In this equation

$\left[\mathbf{H}_{2} \mathbf{O}_{2}\right]=\left[\mathbf{H}_{2} \mathbf{O}_{2}\right]_{\text {border }}$

$\triangle x=21 \AA$, the length of the lipid layer is determined by a previous study. ${ }^{5}$ The local $\mathrm{H}_{2} \mathrm{O}_{2}$ concentration in the external border of the lipid layer can be estimated from its partition coefficient between water and 1-heptane.

$\mathbf{K}_{\mathbf{p}}=\frac{\left[\mathbf{H}_{2} \mathbf{O}_{2}\right]_{\text {water }}}{\left[\mathbf{H}_{2} \mathbf{O}_{2}\right]_{\text {n-heptane }}}$

Combining (S2), (S3), and (S4) gives

$\mathrm{D}=\frac{\text { Flow Rate } \Delta x \mathrm{~K}_{\mathrm{p}}}{\left[\mathrm{H}_{2} \mathbf{O}_{2}\right]_{\text {border }}}$

The flow rate refers to the rate of entrance per unit of liposomal surface

Flow Rate $=\mathbf{k}_{+}\left[\mathrm{H}_{2} \mathrm{O}_{2}\right]_{\text {bulk water }}$

Hence

$\mathbf{D}=\mathbf{k}_{+} \Delta x \mathbf{k}_{\mathbf{p}}$

From equation (S8), the diffusion coefficient of $\mathrm{H}_{2} \mathrm{O}_{2}$ at $25{ }^{\circ} \mathrm{C}$ in a DMPC layer is calculated to be $7 \times 10^{-8} \mathrm{~cm}^{2} / \mathrm{s}$. Hence, based on the equation (S9), the time required for a $\mathrm{H}_{2} \mathrm{O}_{2}$ molecule to diffuse through the HBM system is less than $5 \mathrm{~ns}^{4}$ 


$$
\begin{aligned}
& t \\
& =\frac{x^{2} \pi}{4 D}
\end{aligned}
$$

where $t$ is the elapsed time, $D$ is the diffusion coefficient of $\mathrm{H}_{2} \mathrm{O}_{2}$ in DMPC, $x$ is the $\mathrm{H}_{2} \mathrm{O}_{2}$ travel average distance.

Since the experimental time scales are in the range of $1 \mathrm{~s}, \mathrm{H}_{2} \mathrm{O}_{2}$ can be replenished at the SAM-lipid interface during electrocatalysis.

At room temperature $\left(25^{\circ} \mathrm{C}\right)$, the specific activity of $\mathrm{H}_{2} \mathrm{O}_{2}$ permeation in DMPC liposomes is around $25 \%$ higher than the specific activity of $\mathrm{H}_{2} \mathrm{O}_{2}$ permeation in low temperature $\left(4{ }^{\circ} \mathrm{C}\right) .{ }^{6}$ We can estimate that the diffusion coefficient of $\mathrm{H}_{2} \mathrm{O}_{2}$ in DMPC decreases correspondingly in low temperature. The $\mathrm{H}_{2} \mathrm{O}_{2}$ travel time through lipid is less than $78 \mathrm{~ns}$ which is far shorter than the experimental time scales, thereby giving $\mathrm{H}_{2} \mathrm{O}_{2}$ sufficient time to penetrate the lipid membrane.

Given to the partition coefficient of $\mathrm{H}_{2} \mathrm{O}_{2}$ between water and 1-heptane is 1600 at $25{ }^{\circ} \mathrm{C}$, and the experimental $\mathrm{H}_{2} \mathrm{O}_{2}$ solution is $50 \mathrm{mM}$, the concentration of $\mathrm{H}_{2} \mathrm{O}_{2}$ in the HBM system is estimated to be $0.03 \mathrm{mM}$. Although the concentration of $\mathrm{H}_{2} \mathrm{O}_{2}$ is low in the lipid region, with the high $\mathrm{H}_{2} \mathrm{O}_{2}$ travel time through the lipid, it is estimated that the consumed $\mathrm{H}_{2} \mathrm{O}_{2}$ can be replenished within the timescale of the electrocatalytic experiments, thus $\mathrm{H}_{2} \mathrm{O}_{2}$ oxidation can be studied using HBMs. 
(a)

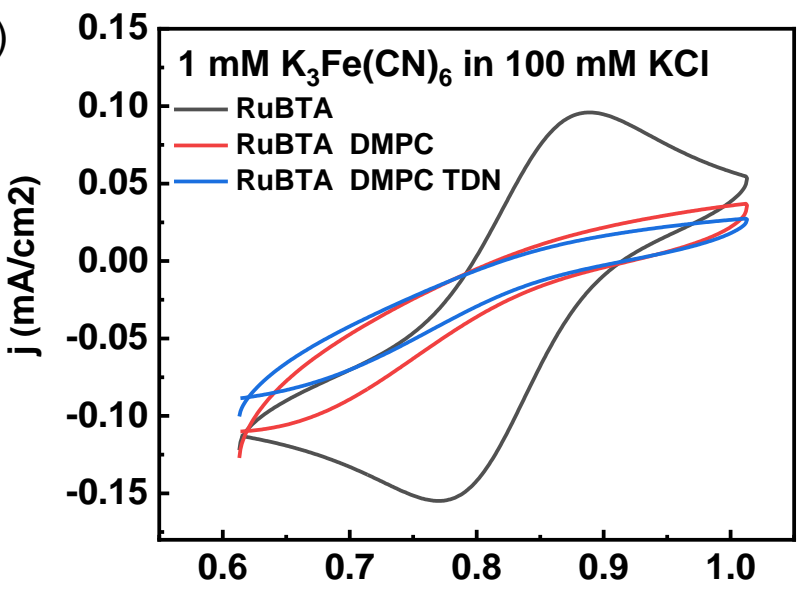

(b)

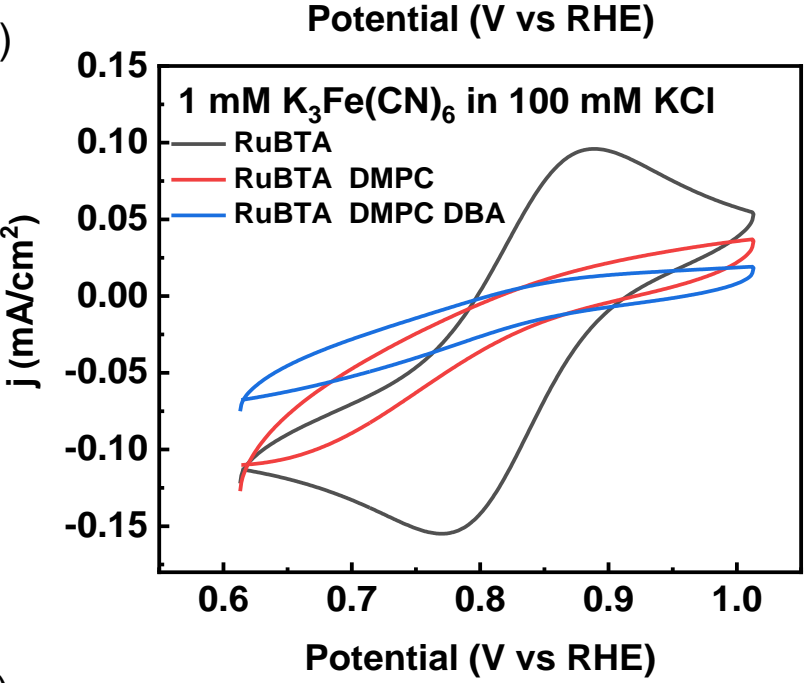

(c)

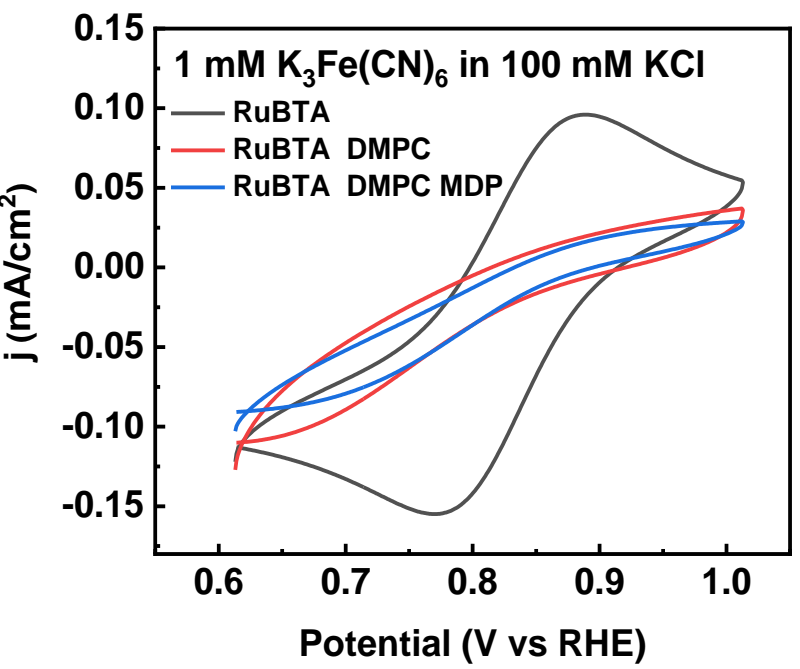

Figure S7. CVs of a RuBTA SAM (black), a HBM containing RuBTA with a lipid layer (red), a HBM containing RuBTA with proton carriers (i.e. (a) TDN, (b) DBA, and (c) $\mathrm{MDP}$ ) in the lipid layer (blue) in a solution of $1 \mathrm{mM} \mathrm{K}_{3} \mathrm{Fe}(\mathrm{CN})_{6}$ with $100 \mathrm{mM} \mathrm{KCl}$ at a scan rate of $50 \mathrm{mV} / \mathrm{s}$. 
The integrity of RuBTA HBMs was analyzed via blocking experiments using $\mathrm{K}_{3} \mathrm{Fe}(\mathrm{CN})_{6}$ as redox probes. In the absence of a lipid layer, a distinct $\mathrm{Fe}(\mathrm{II}) / \mathrm{Fe}(\mathrm{III})$ redox couple can be observed as electron transfer between the SAM electrode and $\mathrm{K}_{3} \mathrm{Fe}(\mathrm{CN})_{6}$ is facile. Upon appending of a lipid layer on top of the RuBTA SAM, the current density of the $\mathrm{Fe}(\mathrm{II}) / \mathrm{Fe}$ (III) redox couple decreased dramatically, suggesting that the RuBTA HBMs are well-formed. ${ }^{7}$ Moreover, with the incorporation of proton carriers into the lipid layer, the current density of the $\mathrm{Fe}(\mathrm{II}) / \mathrm{Fe}(\mathrm{III})$ redox couple is similar to the lipid only case, indicating that the addition of proton carriers does not impact the integrity of the lipid membrane in HBMs (Figure S7). 

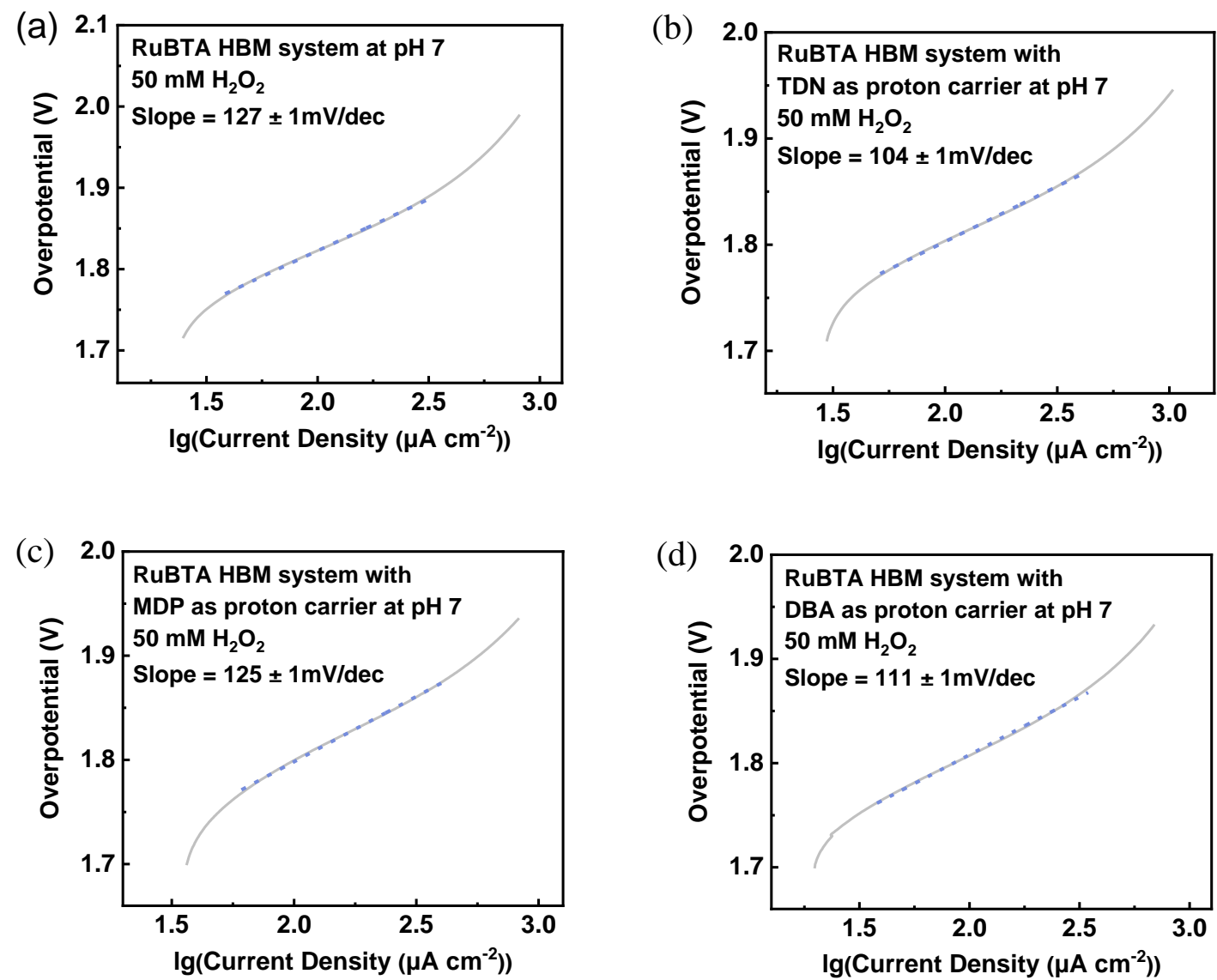

Figure S8. $\mathrm{H}_{2} \mathrm{O}_{2}$ oxidation Tafel slopes of (a) a Ru HBM with lipid only; and Ru HBMs with (b) TDN, (c) MDP, and (d) DBA as proton carriers in the lipid layer, respectively. 
(a)

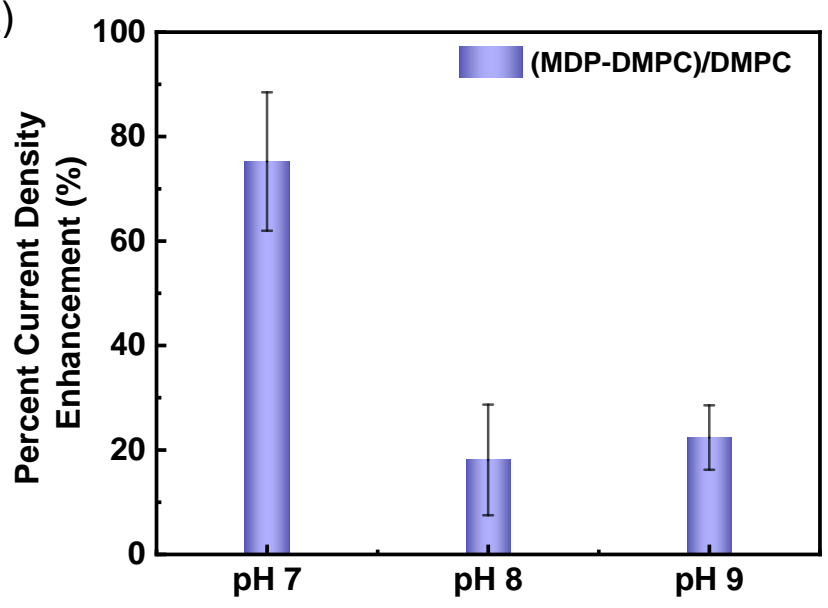

(b)
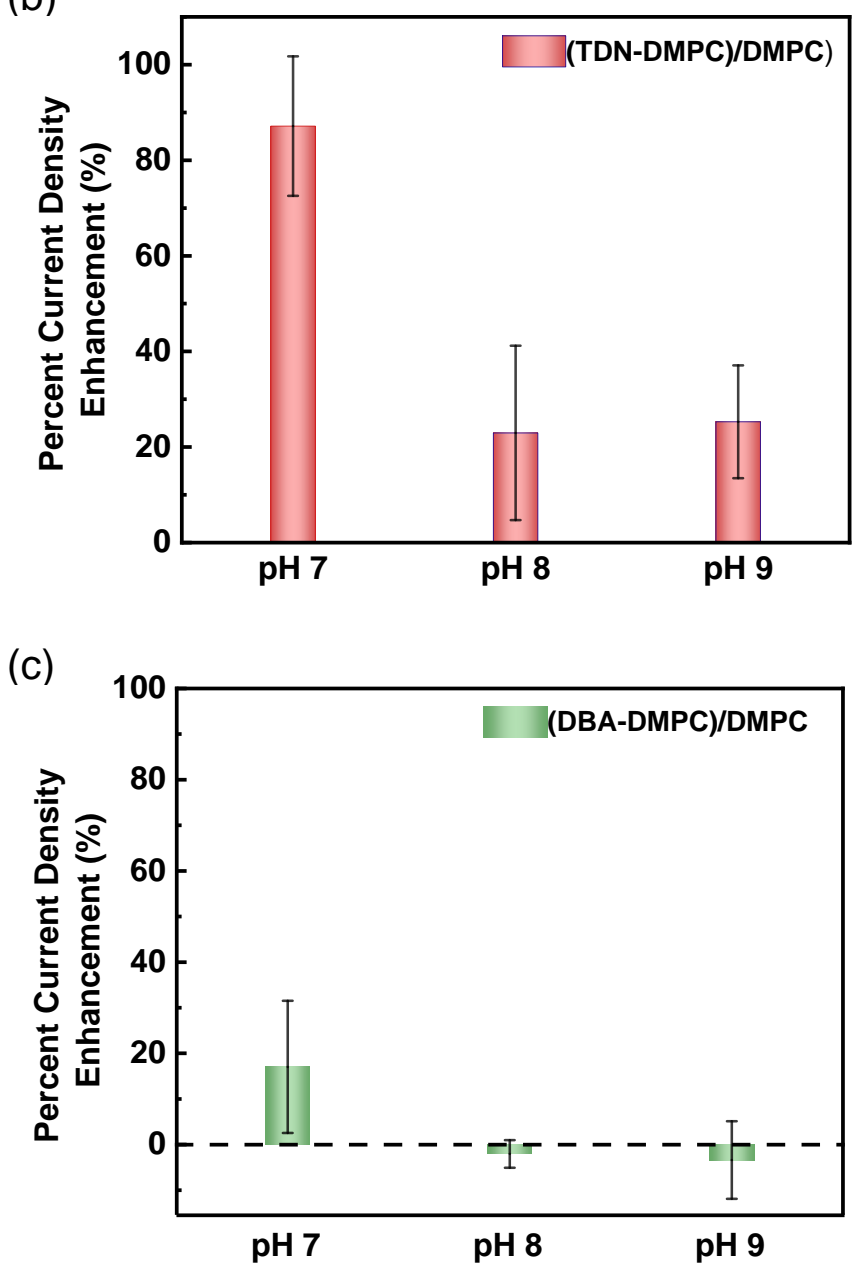

Figure S9. Percent enhancement of $\mathrm{H}_{2} \mathrm{O}_{2}$ oxidation current density at $1.45 \mathrm{~V}$ vs RHE upon adding catalytic amounts of (a) MDP, (b) TDN, and (c) DBA in the DMPC layer as compared to the RuBTA HBM with lipid only in $\mathrm{pH} 7,8$, and 9. 
1

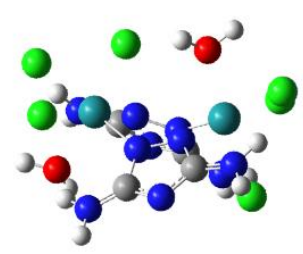

4

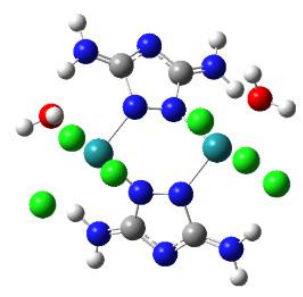

7

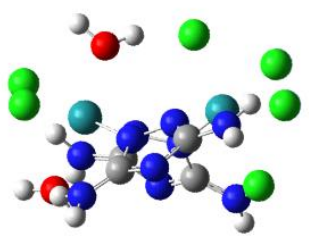

2

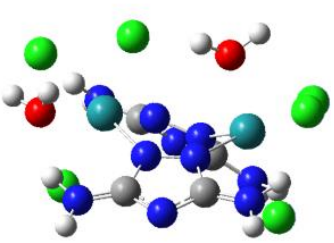

5

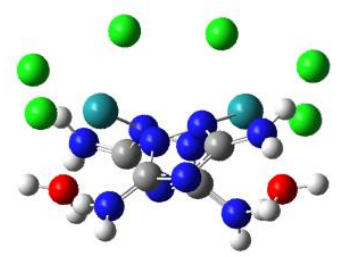

8

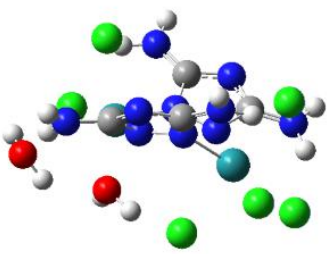

3

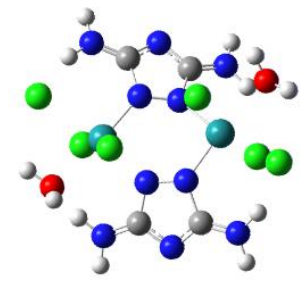

6

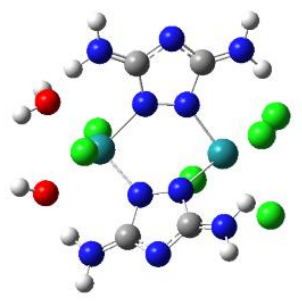

9

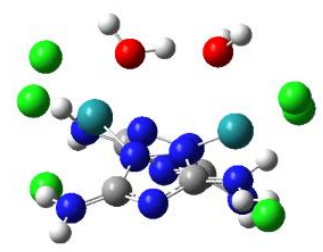

Figure S10. Nine plausible structures of RuDAT. Ru (turquoise); Cl (green); N (blue); $\mathrm{H}$ (white); O (red); C (grey).

RuDAT was fully optimized starting from the chemical composition obtained from XPS. Different $\mathrm{H}_{2} \mathrm{O}$ coordination locations are responsible for different RuDAT structures (Figure S10). After optimization, the structure with the lowest energy is Structure 9, which would be considered as the starting configuration of the resting state utilized in downstream mechanistic considerations (Figure S11). 


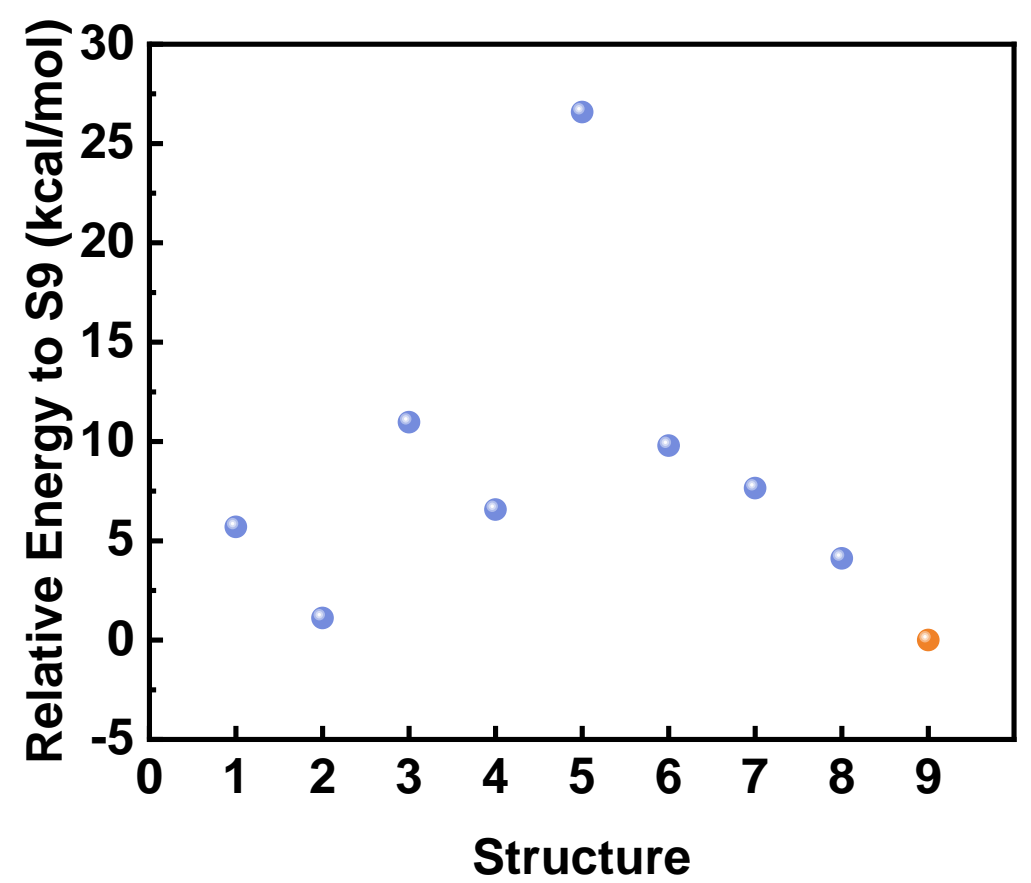

Figure S11. The energy differences among the nine plausible RuDAT structures shown in Figure S9 relative to Structure 9 (orange dot) with the lowest energy calculated.

Optimized coordinates (xyz) optimized at the B3LYP level of theory for selected structures are listed below.

\section{$\mathrm{Ru}_{2}(\mathrm{DAT})_{2}\left(\mathrm{H}_{2} \mathrm{O}\right)_{2} \mathrm{Cl}_{6}$}

$\begin{array}{lrrr}\mathrm{N} & -0.64226900 & 1.50977000 & -0.17067400 \\ \mathrm{~N} & 0.66358800 & 1.36927800 & -0.47134700 \\ \mathrm{~N} & -0.03019000 & 3.37610600 & -1.41494900 \\ \mathrm{~N} & -2.22916800 & 3.31376200 & -0.52286300 \\ \mathrm{~N} & 2.18077700 & 2.63896600 & -1.89302400 \\ \mathrm{C} & -1.03673900 & 2.79052500 & -0.70986200 \\ \mathrm{C} & 1.00645500 & 2.52089300 & -1.31299000 \\ \mathrm{H} & -2.92633200 & 2.83288000 & 0.06015400 \\ \mathrm{H} & -2.44434100 & 4.21693600 & -0.93932200\end{array}$




\begin{tabular}{|c|c|c|c|}
\hline $\mathrm{H}$ & 2.90108100 & 1.92406700 & -1.77272300 \\
\hline $\mathrm{H}$ & 2.37044400 & 3.45139200 & -2.47692100 \\
\hline $\mathrm{N}$ & -0.68555100 & -1.38364000 & -0.44445700 \\
\hline $\mathrm{N}$ & 0.62795400 & -1.51776800 & -0.17474300 \\
\hline $\mathrm{N}$ & -0.01142000 & -3.40258200 & -1.37665500 \\
\hline $\mathrm{N}$ & -2.23118500 & -2.66751500 & -1.82138000 \\
\hline $\mathrm{N}$ & 2.20804200 & -3.32209700 & -0.53746400 \\
\hline $\mathrm{C}$ & -1.04682400 & -2.54818800 & -1.26157500 \\
\hline $\mathrm{C}$ & 1.01076000 & -2.80200700 & -0.70558900 \\
\hline $\mathrm{H}$ & -2.43235600 & -3.48327000 & -2.39667200 \\
\hline $\mathrm{H}$ & -2.95265800 & -1.95734300 & -1.68326000 \\
\hline $\mathrm{H}$ & 2.41428800 & -4.23201400 & -0.94323800 \\
\hline $\mathrm{H}$ & 2.91863900 & -2.83343700 & 0.01965900 \\
\hline $\mathrm{Ru}$ & 1.90681900 & 0.05578700 & 0.30478300 \\
\hline $\mathrm{Ru}$ & -1.90429200 & -0.06342800 & 0.32820900 \\
\hline $\mathrm{Cl}$ & -3.53398700 & -1.83864300 & 0.85309000 \\
\hline $\mathrm{Cl}$ & -3.42798500 & 1.44653000 & 1.61033200 \\
\hline $\mathrm{Cl}$ & 3.46619800 & -1.43975500 & 1.57434800 \\
\hline $\mathrm{Cl}$ & -3.05211600 & 0.38829700 & -1.79928400 \\
\hline $\mathrm{Cl}$ & 3.01874900 & -0.39060700 & -1.82837000 \\
\hline $\mathrm{O}$ & -1.10134200 & -0.50918700 & 2.20060400 \\
\hline $\mathrm{H}$ & -0.19576700 & -0.09451400 & 2.38342800 \\
\hline $\mathrm{H}$ & -1.74193300 & -0.38821700 & 2.92876200 \\
\hline $\mathrm{O}$ & 1.22910700 & 0.44902500 & 2.34331400 \\
\hline $\mathrm{H}$ & 1.82050700 & -0.06770800 & 2.93870200 \\
\hline
\end{tabular}




\section{$\mathrm{Ru}_{2}(\mathrm{DAT})_{2} \mathrm{Cl}_{6} \mathrm{HOOH}$}

\begin{tabular}{|c|c|c|c|}
\hline $\mathrm{N}$ & 0.74171100 & -1.38498900 & -0.54978800 \\
\hline $\mathrm{N}$ & -0.59324200 & -1.50371800 & -0.44327200 \\
\hline $\mathrm{N}$ & 0.14846700 & -3.37745300 & -1.58190800 \\
\hline $\mathrm{N}$ & 2.45390300 & -2.76437800 & -1.59286500 \\
\hline $\mathrm{N}$ & -2.17453200 & -3.21320000 & -1.08718500 \\
\hline $\mathrm{C}$ & 1.18770300 & -2.57309800 & -1.28923300 \\
\hline $\mathrm{C}$ & -0.94237400 & -2.74813800 & -1.05548600 \\
\hline $\mathrm{H}$ & 3.16917100 & -2.08715200 & -1.32335900 \\
\hline $\mathrm{H}$ & 2.72441100 & -3.59918900 & -2.10989400 \\
\hline $\mathrm{H}$ & -2.93462100 & -2.71402500 & -0.62471100 \\
\hline $\mathrm{H}$ & -2.36221600 & -4.10165300 & -1.54641200 \\
\hline $\mathrm{N}$ & 0.59013900 & 1.52412200 & -0.40275000 \\
\hline $\mathrm{N}$ & -0.74300500 & 1.40488900 & -0.52547000 \\
\hline $\mathrm{N}$ & -0.14485900 & 3.40390400 & -1.54046100 \\
\hline $\mathrm{N}$ & 2.17374200 & 3.24000500 & -1.02689600 \\
\hline $\mathrm{N}$ & -2.45015300 & 2.78767400 & -1.56771600 \\
\hline $\mathrm{C}$ & 0.94238800 & 2.77366700 & -1.00738700 \\
\hline $\mathrm{C}$ & -1.18510600 & 2.59739500 & -1.25813500 \\
\hline $\mathrm{H}$ & 2.36494700 & 4.12890100 & -1.48386400 \\
\hline $\mathrm{H}$ & 2.92565300 & 2.74605400 & -0.54344700 \\
\hline $\mathrm{H}$ & -2.71946200 & 3.62292700 & -2.08456900 \\
\hline
\end{tabular}




$\begin{array}{lrrr}\mathrm{H} & -3.16666700 & 2.11250800 & -1.29658600 \\ \mathrm{Ru} & -1.80725300 & 0.00304700 & 0.31875000 \\ \mathrm{Ru} & 1.80589000 & -0.00033600 & 0.32783100 \\ \mathrm{Cl} & 3.26273800 & -1.73925700 & 1.28618100 \\ \mathrm{Cl} & -3.30270800 & 1.69999800 & 1.29149800 \\ \mathrm{Cl} & 3.28346100 & 0.26814000 & -1.58985800 \\ \mathrm{Cl} & -3.28871300 & -0.25106800 & -1.59704300 \\ \mathrm{O} & -0.66546300 & 0.36802000 & 2.06256700 \\ \mathrm{O} & 0.69527800 & -0.31329200 & 2.12962600 \\ \mathrm{Cl} & 3.09200700 & 1.69041800 & 1.57409900 \\ \mathrm{Cl} & -3.02491500 & -1.71084100 & 1.60101000 \\ \mathrm{H} & -1.07607600 & 0.20848100 & 2.95478800 \\ \mathrm{H} & 0.49363900 & -1.26650200 & 2.34048100\end{array}$

\section{$\mathrm{Ru}_{2}(\mathrm{DAT})_{2} \mathrm{Cl}_{6} \mathrm{OO}$}

$\begin{array}{llll}\mathrm{N} & 0.70143600 & -1.50121500 & -0.39743700 \\ \mathrm{~N} & -0.60658100 & -1.45828100 & -0.55314700 \\ \mathrm{~N} & 0.11783900 & -3.42705900 & -1.54986700 \\ \mathrm{~N} & 2.42137200 & -3.11256400 & -1.00488900 \\ \mathrm{~N} & -2.20599000 & -2.91193800 & -1.66813100 \\ \mathrm{C} & 1.15746400 & -2.76125400 & -1.00801100 \\ \mathrm{C} & -0.97063900 & -2.66174300 & -1.30444800 \\ \mathrm{H} & 3.12638200 & -2.55560000 & -0.51666300 \\ \mathrm{H} & 2.70294700 & -3.98049000 & -1.46105000 \\ \mathrm{H} & -2.95490800 & -2.23564600 & -1.50159700\end{array}$




\begin{tabular}{|c|c|c|c|}
\hline $\mathrm{H}$ & -2.41378100 & -3.77041600 & -2.17824300 \\
\hline $\mathrm{N}$ & 0.64139800 & 1.41503700 & -0.53936500 \\
\hline $\mathrm{N}$ & -0.68761800 & 1.49183800 & -0.47428200 \\
\hline $\mathrm{N}$ & -0.00523500 & 3.38500400 & -1.60396300 \\
\hline $\mathrm{N}$ & 2.32289000 & 2.87210600 & -1.55600100 \\
\hline $\mathrm{N}$ & -2.33062300 & 3.12877600 & -1.12816800 \\
\hline $\mathrm{C}$ & 1.06104400 & 2.63344800 & -1.28267200 \\
\hline $\mathrm{C}$ & -1.08110200 & 2.72233200 & -1.09950900 \\
\hline $\mathrm{H}$ & 2.56999700 & 3.71402800 & -2.07626000 \\
\hline $\mathrm{H}$ & 3.06424800 & 2.22915000 & -1.27038700 \\
\hline $\mathrm{H}$ & -2.55996500 & 4.01400800 & -1.57740500 \\
\hline $\mathrm{H}$ & -3.06835500 & 2.59691500 & -0.65999200 \\
\hline $\mathrm{Ru}$ & -1.78936500 & -0.04733900 & 0.41747500 \\
\hline $\mathrm{Ru}$ & 1.75499400 & 0.04928900 & 0.35737100 \\
\hline $\mathrm{Cl}$ & 3.11813700 & -1.52230800 & 1.64057900 \\
\hline $\mathrm{Cl}$ & -3.30800300 & 1.54202100 & 1.49824100 \\
\hline $\mathrm{Cl}$ & 3.33844400 & -0.08740900 & -1.50814200 \\
\hline $\mathrm{Cl}$ & -3.24413200 & 0.05242000 & -1.56449500 \\
\hline $\mathrm{O}$ & -0.74956300 & 0.20289300 & 1.99482800 \\
\hline $\mathrm{O}$ & 0.61817300 & 0.05191600 & 2.09875200 \\
\hline $\mathrm{Cl}$ & 3.08119100 & 1.84738800 & 1.33467800 \\
\hline $\mathrm{Cl}$ & -3.07304500 & -1.88534000 & 1.29880600 \\
\hline
\end{tabular}



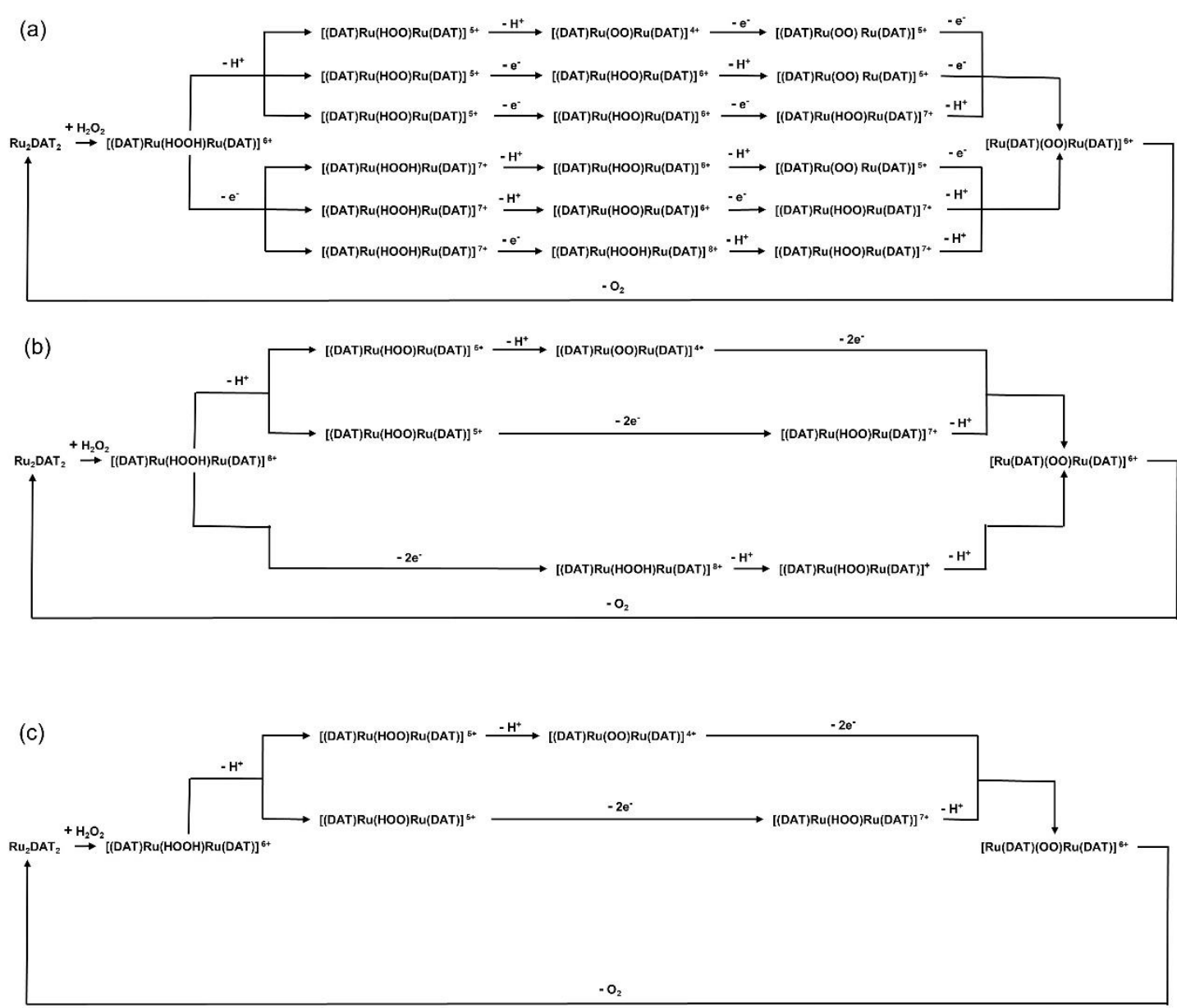

Figure S12. Plausible reaction pathways of $\mathrm{H}_{2} \mathrm{O}_{2}$ oxidation to $\mathrm{O}_{2}$ by $\mathrm{Ru}(\mathrm{III}) \mathrm{DAT}$. 


\section{Supplementary References}

1. Li, Y.; Tse, E. C. M.; Barile, C. J.; Gewirth, A. A.; Zimmerman, S. C., Photoresponsive Molecular Switch for Regulating Transmembrane Proton-Transfer Kinetics. J. Am. Chem. Soc. 2015, 137, 14059-14062.

2. Rowe, G. K.; Creager, S. E., Interfacial Solvation and Double-Layer Effects on Redox Reactions in Organized Assemblies. J. Phys. Chem. 1994, 98, 5500-5507.

3. Hosseini, A.; Collman, J. P.; Devadoss, A.; Williams, G. Y.; Barile, C. J.; Eberspacher, T. A., Ferrocene Embedded in an Electrode-Supported Hybrid Lipid Bilayer Membrane: A Model System for Electrocatalysis in a Biomimetic Environment. Langmuir 2010, 26, 17674-17678.

4. Abuin, E.; Lissi, E.; Ahumada, M., Diffusion of hydrogen peroxide across DPPC large unilamellar liposomes. Chem. Phys. Lipids 2012, 165, 656-661.

5. Barile, C. J.; Edmund, C.; Li, Y.; Sobyra, T. B.; Zimmerman, S. C.; Hosseini, A.; Gewirth, A. A., Proton switch for modulating oxygen reduction by a copper electrocatalyst embedded in a hybrid bilayer membrane. Nat. Mater. 2014, 13, 619-623.

6. Mathai, J. C.; Sitaramam, V., Stretch sensitivity of transmembrane mobility of hydrogen peroxide through voids in the bilayer. Role of cardiolipin. J. Biol. Chem. 1994, 269, 17784-17793.

7. Han, X.; Wang, L.; Qi, B.; Yang, X.; Wang, E., A Strategy for Constructing a Hybrid Bilayer Membrane Based on a Carbon Substrate. Anal. Chem. 2003, 75, 6566-6570. 